\title{
Life cycle assessment of biofuels from an integrated Brazilian algae- sugarcane biorefinery
}

\begin{abstract}
Sugarcane ethanol biorefineries in Brazil produce carbon dioxide, electricity and heat as byproducts. These are essential inputs for algae biodiesel production. In this paper, we assessed ethanol's life cycle greenhouse gas emissions and fossil energy use produced in an integrated sugarcane and algae biorefinery where biodiesel replaces petroleum diesel for all agricultural operations. Carbon dioxide from cane juice fermentation is used as the carbon source for algae cultivation, and sugarcane bagasse is the sole source of energy for the entire facility. Glycerin produced from the biodiesel plant is consumed by algae during the mixotrophic growth phase. We assessed the uncertainties through a detailed Monte-Carlo analysis. We found that this integrated system can improve both the life cycle greenhouse gas emissions and the fossil energy use of sugarcane ethanol by around $10 \%$ and 50\%, respectively, compared to a traditional Brazilian sugarcane ethanol distillery.
\end{abstract}

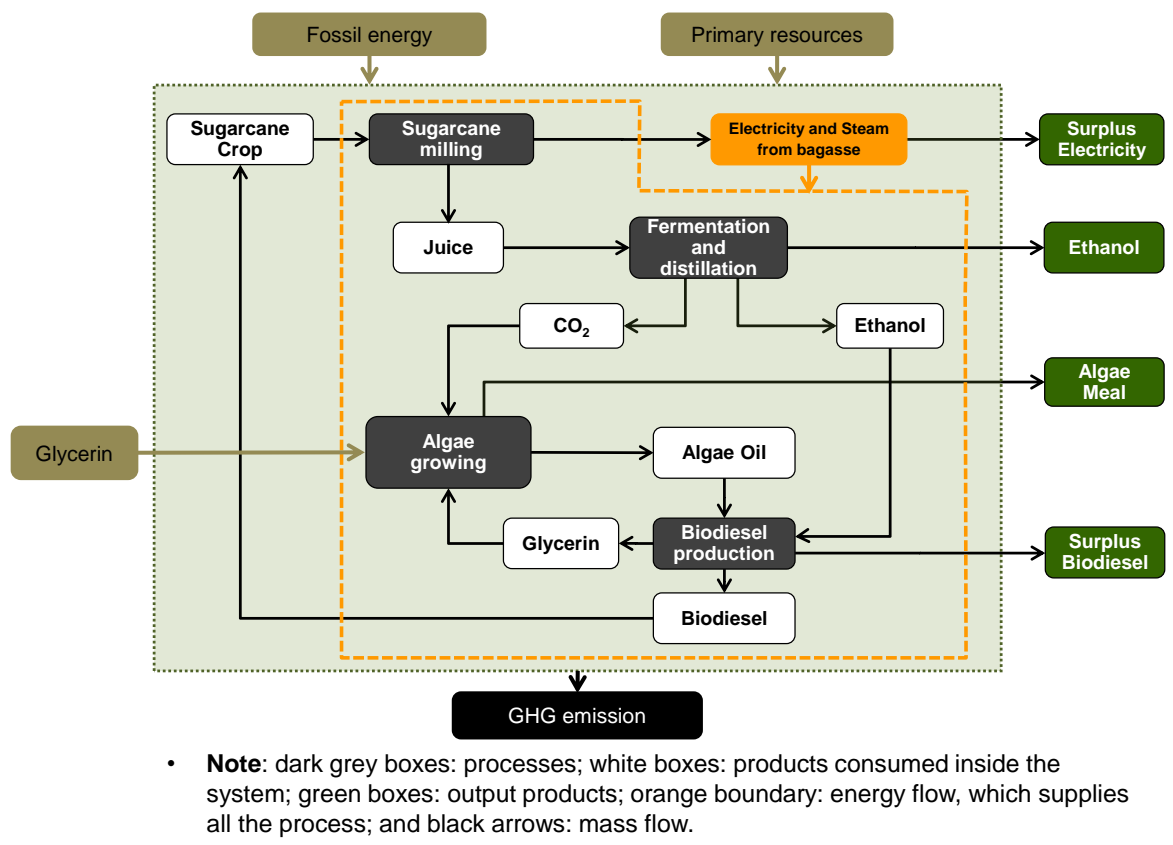

KEYWORDS: ethanol; biodiesel; LCA; uncertainty analysis; sustainability.

\footnotetext{
* Corresponding author at: Faculdade de Engenharia Mecânica, Unicamp. Rua Mendeleyev 200, Cidade Universitária

“Zeferino Vaz", Postal Code 13083-860 (J.E.A. Seabra).

E-mail address: sp.souza@yahoo.com.br (S.P. Souza).

Phone.: +55 1935213284 (J.E.A. Seabra).
} 


\section{Introduction}

Interest in algae derived bioenergy began more than 50 years ago [1]. The first oil crisis spurred the establishment of large research programs in Japan and in the United States on algae biofuel production [2]. In addition to the high productivity and oil content of microalgae [3], algae derived biodiesel has properties similar to petroleum diesel in viscosity, density, flash point, solidifying point, cold filter plugging point and $\mathrm{H} / \mathrm{C}$ ratio [4].

More than $10^{5}$ species of microalgae can be used as feedstock for biodiesel production [5]. Green algae, diatoms and cyanobacteria (blue-green algae) are the most promising biofuel feedstocks [1]. Microalgae are made up of long-chain fatty acids, proteins and carbohydrates in high concentration, making them a rich source of ingredients for pharmaceutical and nutraceutical products (e.g. antibiotics, algaecides, vitamins, functional foods), as well as biodiesel $[1,6]$.

Microalgae have lower harvesting and transportation costs than woody or herbaceous biomass. They do not need arable land, pesticides or herbicides for cultivation. They can also be produced in wide range of environmental conditions such as fresh, brackish or salt water, or effluent with high organic load concentration [6,7]. Finally, microalgae biodiesel production results in high value co-products [8]. However, algae production still has many challenges due to high technology barriers and costs. All the preferred microalgae characteristics like cells with high yield under high light intensity, thin membranes, easy flocculation, fast growth and high lipid content are not found concurrently in one ideal strain [2]. Hence, current applications of algae biodiesel production are restricted to special, niche cases of viability like we identify in this paper.

Light, water, nutrients and $\mathrm{CO}_{2}$ are essential inputs for algae production. Due to a favorable climate, Brazil has the potential to become a major algae producer [9]. Further, the Brazilian sugarcane sector is an excellent source of pure $\mathrm{CO}_{2}$, which is generated during sugarcane juice fermentation, along with substantial quantities from the combined heat and power system.

At the same time, onsite diesel consumption is responsible for $2 / 3$ of the fossil energy consumption and $1 / 3$ of the greenhouse gases (GHG) emissions in the sugarcane ethanol life cycle [10]. With an average consumption of $4 \mathrm{~L} / \mathrm{t}$ sugarcane [10], it is estimated that the sugarcane sector alone was responsible for about $4 \%$ of all diesel consumption in Brazil in 2013 $[11,12]$. Given these reasons, we designed an integrated algae-sugarcane biorefinery to explore how it can affect the life cycle performance of the products from a traditional sugarcane ethanol factory. 
We evaluated the life cycle fossil energy use and greenhouse gas (GHG) emissions of the biofuels produced in such integrated biorefinery using an attributional LCA method. The hypothesis is that replacing diesel by algae biodiesel can substantially improve the life cycle GHG profile of sugarcane ethanol. Such an integrated plant is novel and we could not find any study that performs an LCA of the same. We do recognize however, that such a factory is not yet commercial primarily due to technological and economic barriers for algae production. Nevertheless, algae have been identified as a promising feedstock for biodiesel production [7] and integrating its production with a sugarcane ethanol factory will help reduce costs by taking advantage of synergies that substantially improve overall system efficiency. For example, algae requires pure carbon dioxide for the photosynthesis process, heat and electricity all of which are produced in excess in the sugarcane ethanol process [13].

\section{Microalgae as feedstock for biodiesel production}

Microalgae are prokaryotic (cyanobacteria) or eukaryotic (green algae, red algae and diatoms) photosynthetic microorganisms that can be found in both marine and freshwater ecosystems $[6,14,15]$. When compared with land-based plants, their photosynthetic mechanism is generally more efficient in converting solar energy into biomass because they are submerged in an aqueous ecosystem that allows for efficient access to water, $\mathrm{CO}_{2}$ and other nutrients [15]. They are easily cultured due to the unicellular or simple multi-cellular cell structure, able to grow rapidly and live in a wide range of environmental conditions $[6,14]$. However, land-based crops use the surface of their leaves to receive, reflect and dissipate the light, while algae are limited to using only the light at the water surface. Hence, algae need to receive stirring in order to ensure access to $\mathrm{CO}_{2}[3]$.

Algae metabolism can be photoautotrophic, photoheterotrophic, heterotrophic or mixotrophic, and depending on the environmental conditions, the same species can shift from one process to another. Photoautotrophic metabolism utilizes sunlight as the energy source and $\mathrm{CO}_{2}$ as the inorganic carbon source. Photoheterotrophic metabolism requires sunlight for energy but uses organic substrate as the carbon source. Heterotrophic metabolism does not depend on light and utilizes an organic substrate (e.g. glucose, acetate, and glycerol) as both the energy and carbon source. In the mixotrophic metabolic process microalgae are able to grow in both heterotrophic and photoautotrophic pathways depending on the concentration of organic carbon sources and light intensity $[1,6,16]$.

There is a wide range of lipid content in microalgae species (1-70\% of dry weight) and high oil content is frequently associated with low biomass yield. Thus, it is important to 
select microalgae species that have high lipid content and high biomass productivity [6]. Other desired microalgae characteristics from a biodiesel perspective are cells with thin membranes, high yield under high light intensity, and that easily flocculate [2]. As we mention above, not all of these features are found in a single species so the choice of species involves tradeoffs between features.

Biodiesel production from microalgae consists of the growth of cells, followed by separation of the cells from the culture media and lipid extraction [17]. In the following sections, we discuss briefly the microalgae production process. A more detailed description of microalgae is presented in the literature $[1,2,14,16,18,17,19-22]$.

\subsection{Production system}

Open ponds and photobioreactors (PBRs) are the two most common engineered systems used for microalgae cultivation. Both systems require light, nutrients and $\mathrm{CO}_{2}$ [23], where the light and temperature are especially crucial factors for growing algae [6]. Currently, neither open ponds nor closed photobioreactors are mature technologies for biofuel production [8]. Open ponds can be designed as raceways, tanks or circular ponds, but raceways have become the most popular since motorized paddlewheels have been used for continuous circulation [8]. Mixing and circulation are required to prevent sedimentation and to stabilize algae growth and productivity [14]. $\mathrm{CO}_{2}$ must be sparged into counter-current water flow [1]. Biomass productivity in open ponds is less efficient due to evaporation losses, temperature fluctuation, $\mathrm{CO}_{2}$ deficiencies, inefficient mixing, and light limitation [14]. Besides, they are more susceptible to culture crashes once they are directly in contact with the environment and thus amenable to introduction of invasive algal species as well as predators and pathogens [24]. Hence, in this paper, we design algae growth using photobioreactors.

Photobioreactors are enclosed tanks with several geometries and designs, such as flatplate, airlift tubular, vertical columns, hemispherical domes, among others [8,22]. Water, nutrients and $\mathrm{CO}_{2}$ are supplied in a controlled way and $\mathrm{O}_{2}$ has to be removed. Sunlight diffuses into the PBR through transparent walls or through light fiber or tubes $[2,15]$. Several methods can be used for biomass harvesting and drying. Microalgae species, properties such as cell size and density, culture conditions [15] and the desired co-products [25] will define the harvesting and drying technique.

Once the algae are harvested from the PBR, lipids are extracted. Conventional solvent extraction, supercritical fluid or heated oil extraction, mechanical extraction, biological extraction and fractionation can all be used for algal lipid recovery [26]. The choice depends 
on the pre-treatment of algal biomass, which can provide a biomass concentrate or dried powder [27], and on the species and its cell wall physical properties, which also depends on

\section{Integrated algae-sugarcane biorefinery}

In the proposed integrated biorefinery, sugarcane and algae are processed in a combined ethanol-biodiesel plant, which uses only bagasse as fuel for cogeneration. We assumed the algae production process developed by SEE ALGAE ${ }^{1}$ Technology (SAT) company. We made some adjustments to their system to fit our design needs. Carbon dioxide is captured from the sugarcane juice fermentation process to feed the algae production in a photobioreactor, which also receives sunlight (solar prism). Algae flows to a mixotrophic reactor fed with organic carbon source and fertilizers. The mixotrophic process also receives a small quantity of carbon dioxide.

Flocculation and flotation are followed by a de-watering process employed by SAT. We are unable to disclose the full details of the de-watering method and chemicals used in this process due to our non-disclosure agreement with SAT. We modeled di-methyl ether (DME) lipid extraction and transesterification to convert algae oil into biodiesel.

We chose the microalgae species $N$. salina because of its high lipid content and high biomass productivity [29]. Glycerin is used as carbon source because it is available as a coproduct of biodiesel production onsite and because $N$. salina has demonstrated a better carbon assimilation using this substrate [30].

It is important to highlight that we are only using $\mathrm{CO}_{2}$ from the fermentation process because it is pure [13]. Additional $\mathrm{CO}_{2}$ could be provided from biomass burning (bagassebased cogeneration), but that is not a pure $\mathrm{CO}_{2}$ source and, further, we find that the fermentation process provides enough carbon dioxide for the needs of the integrated biorefinery. However, the $\mathrm{CO}_{2}$ flow needs to be diluted because the growth of microalgae can be inhibited at $\mathrm{CO}_{2}$ concentration above $5 \%$ (pure $\mathrm{CO}_{2}$-air), depending on the species $[31,32]$.

\footnotetext{
${ }^{1}$ SEE ALGAE shared their system design and data with us under a non-disclosure agreement. Hence, all data that we publish in this paper abides by this agreement or is publicly available.
} 


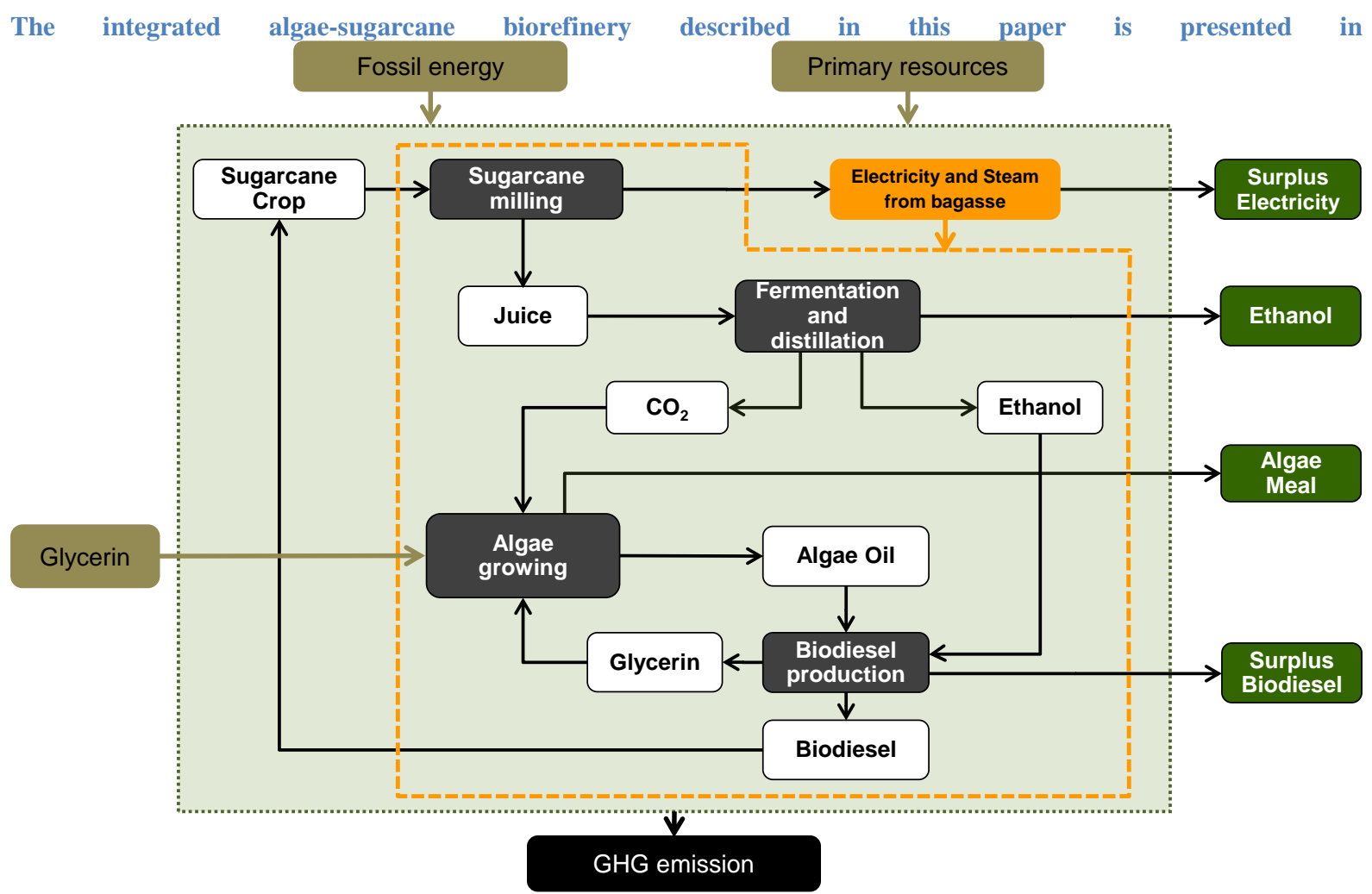

Figure 1 and our main assumptions are:

- We use the algae species Nannochloropsis salina in our biorefinery.

- Carbon dioxide from cane juice fermentation is used as one of the inorganic carbon sources for algae cultivation in photoautotrophic and heterotrophic processes.

- Biodiesel production is constrained by the $\mathrm{CO}_{2}$ availability.

- All glycerin produced from the biodiesel plant is consumed as energy and carbon source in the mixotrophic process. However, the supply is not enough and additional glycerin is bought from the market.

- The alcohol source for transesterification is the ethanol produced onsite.

- Ethanol, electricity, biodiesel and algae meal are the output products of the system.

- The diesel used in the sugarcane cultivation is replaced entirely by biodiesel (B100) without engine modification [33,34].

- Stillage and filtercake are used for fertirrigation and organic fertilization. Filtercake is applied in $100 \%$ of the plant-cane area.

- Sugarcane bagasse is completely used for heat and power generation, supplying the energy demand of the combined plant (ethanol and biodiesel) and producing surplus electricity.

- Fifty percent of the sugarcane area is irrigated. 
Considering that some producers are irrigating the sugarcane production, especially in Mato Grosso and Goiás states, we assumed salvage irrigation in 50\% of the sugarcane area, based on our field data. However, the goal here is not to discuss irrigation and its effects on sugarcane growth, but identify the diesel consumption for this activity. Furthermore, the use of irrigation in sugarcane crops is still incipient in these states, and the procedures and irrigation rates vary within a wide range among the producers.

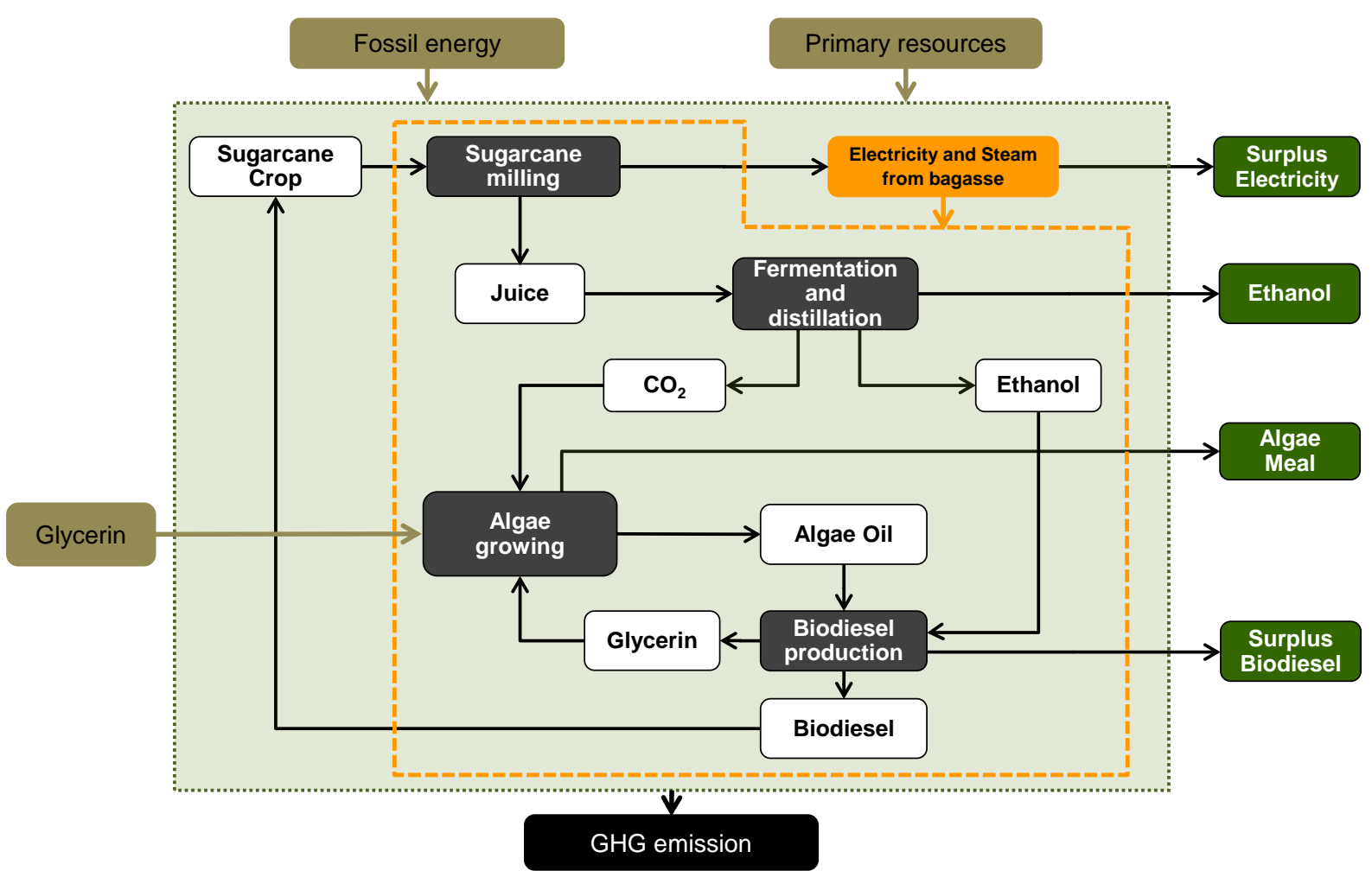

Figure 1. Integrated algae-sugarcane biorefinery.

Note: dark grey boxes: processes; white boxes: products consumed inside the system; green boxes: output products; orange boundary: energy flow, which supplies all the process; and black arrows: mass flow.

\section{Methods}

We applied an attributional life cycle assessment technique $[35,36]$ and chose $1 \mathrm{MJ}$ of hydrous ethanol as the functional unit (FU) for the sugarcane ethanol LCA and $1 \mathrm{MJ}$ of ethyl biodiesel as FU for the algae biodiesel LCA. Note that the goal is to compare the ethanol production (1 MJ of hydrous ethanol) between the traditional and the biorefinery systems. The system boundary, in this cradle-to-gate LCA, includes sugarcane and algae cultivation and biofuel and co-products production. The environmental aspects considered were fossil energy use and GHG emissions. In order to compare the traditional sugarcane ethanol production with our integrated biorefinery, we assessed three product systems: 1) traditional 
ethanol production, 2) algae biodiesel production, and 3) algae-sugarcane biorefinery system. We first present the results for the algae biodiesel life cycle for a better understanding of the impact caused by diesel replacement in the sugarcane cultivation activities. We then present the results for the integrated biorefinery. Using Monte-Carlo simulation we compared these results with the traditional sugarcane ethanol. Each of these systems is described below:

- Traditional system (reference case): A conventional sugarcane production and processing system that uses only diesel (B5) as fuel in the agricultural operations and transportation. Ethanol and electricity are the output products.

- Algae biodiesel system: An algae production system that has meal and biodiesel as products. Biodiesel is produced by transesterification using ethyl route. The electricity, heat and ethanol are provided by the sugarcane mill and by the cogeneration plant. Carbon dioxide is also provided by the sugarcane distillery, but we did not attribute any environmental burden to $\mathrm{CO}_{2}$ as it was not considered as a product of the traditional sugarcane sector.

- Integrated Biorefinery: An integrated production of biodiesel, glycerin, algae meal, ethanol, and electricity. The biodiesel produced is used to replace $100 \%$ of the conventional diesel (B5) consumed in the agricultural operations and sugarcane transport. The system also provides surplus biodiesel. Glycerin is not an output product since algae consume it as a carbon and energy source.

The life cycle fossil energy use and GHG emissions of material and energy inputs were retrieved from Ecoinvent v.2.2. [37] and CTBE's database (Brazilian Bioethanol Science and Technology Laboratory) [38-40], which are specifically for Brazilian conditions (Table S1). All energy flows were calculated in terms of primary fossil energy.

For the integrated biorefinery, we used an energy basis allocation to split the fossil energy and the GHG emissions between ethanol and surplus electricity. For the algae biodiesel system, the products are meal and biodiesel, and we used an allocation based on mass.

\subsection{Input data}

The sugarcane life cycle inventory was based on data collected from sugarcane mills and sugarcane suppliers (Table S2. The data refer to the states of São Paulo, Mato Grosso and Goiás, and were collected employing direct field observation methods through 
questionnaires. In a previous study, we assessed the LCA of a soybean-sugarcane biorefinery system in these regions [41]. Soybean is the main feedstock used for the biodiesel production

Table 1. Agricultural and industrial inputs - sugarcane production

\section{Agricultural parameters}

Number of cuts ${ }^{\text {a }}$ 5

Sugarcane yield ( t/ha.yr $)^{\text {a }}$ 85

Straw yield $(\mathrm{kg} / \mathrm{t} \text { cane; } \mathrm{DW})^{\mathrm{d}}$

Stillage application rate $\left(\mathrm{m}^{3} / \mathrm{ha}\right)^{\mathrm{a}}$

Ash application rate (kg/ha.yr; DW) ${ }^{\text {a }}$

Filter cake application rate (t/ha; DW) ${ }^{\text {a }}$

Agricultural Inputs (kg/ha) ${ }^{\text {a }}$

Nitrogen

84

Phosphorus

Potassium

Insecticide

0.2

Fungicide

0.01

Herbicide

4.1

Limestone

1000

Gypsum $\left(\mathrm{CaSO}_{4}\right)$

Diesel consumption (L/ha.yr)

262.5

Industrial Inputs

$\mathrm{CaO}(\mathrm{g} / \mathrm{t} \text { cane })^{\mathrm{a}}$

Antifoam (g/L ethanol) ${ }^{a}$

0.3

Dispersant (g/L ethanol) ${ }^{a}$

0.3

Sulfuric acid (g/L ethanol) ${ }^{a}$

6.6

Lubricants (g/t cane) ${ }^{\mathrm{b}}$

Cyclohexane ( $\mathrm{g} / \mathrm{L}$ ethanol) ${ }^{\mathrm{a}, \mathrm{c}}$

1.2

Sodium Hydroxide ( $\mathrm{g} / \mathrm{L}$ ethanol) ${ }^{\mathrm{a}}$

\section{Mill processing capacity ( $t$ cane/yr)}

$\mathbf{4 , 0 0 0 , 0 0 0}$

${ }^{a}$ Data provided by visited sugarcane mills and farms. ${ }^{b}[39] .{ }^{c}$ Used to produce anhydrous ethanol (input for the transesterification process). ${ }^{\mathrm{d}}$ [42].

Direct $\mathrm{N}_{2} \mathrm{O}$ emissions from crop residues were estimated according to the IPCC tier 1 method [43]. We did not include the direct $\mathrm{N}_{2} \mathrm{O}$ emissions from the biological nitrogen fixation due to lack of evidence indicating significant emissions arising from this process [4].

The biorefinery cogeneration system operate at $90 \mathrm{bar} / 520^{\circ} \mathrm{C} / 120 \mathrm{t} / \mathrm{h}$ of steam [44] which is able to produce $135.5 \mathrm{kWh}$ of electricity per metric ton of sugarcane. The heat 
demand of the algae plant reduces this amount to $132 \mathrm{kWh}$, while $30 \mathrm{kWh} / \mathrm{t}$ is consumed in the distillery [44] and $21 \mathrm{kWh} / \mathrm{t}$ is used for algae biodiesel production (Table 2). The sugarcane crushers are driven by electric engines. The electricity consumption for algae biomass production, including photobioreactor, flocculation and de-watering, was provided by SAT and cannot be disclosed separately due to our NDA. Other input data for the algae life cycle inventory was based on literature.

Table 2. Demand and supply of steam and electricity of the biorefinery system.

\begin{tabular}{|c|c|c|}
\hline \multicolumn{3}{|l|}{ Electricity consumption } \\
\hline $\mathrm{CO}_{2}$ recovery from fermentation ${ }^{\mathrm{a}}$ & 300 & $\mathrm{kWh} / \mathrm{t}$ biomass $(\mathrm{DW})$ \\
\hline Photobioreactor, flocculation and de-watering ${ }^{b}$ & 374 & $\mathrm{kWh} / \mathrm{t}$ biomass $(\mathrm{DW})$ \\
\hline Oil extraction $(\mathrm{DME})^{\mathrm{c}}$ & 1079 & $\mathrm{kWh} / \mathrm{t}$ extracted oil \\
\hline Transesterification $^{c}$ & 0.38 & $\mathrm{kWh} / \mathrm{t}$ biodiesel \\
\hline \multicolumn{3}{|l|}{ Steam consumption } \\
\hline Oil extraction (DME) ${ }^{d}$ & 5.49 & $\mathrm{MJ} / \mathrm{kg}$ biodiesel \\
\hline Transesterification $^{\mathrm{e}}$ & 3.06 & $\mathrm{MJ} / \mathrm{kg}$ biodiesel \\
\hline \multicolumn{3}{|l|}{ Supply and demand of electricity } \\
\hline Electricity production ${ }^{\mathrm{f}}$ & 132 & $\mathrm{kWh} / \mathrm{t}$ cane \\
\hline Ethanol plant ${ }^{\mathrm{g}}$ & 30 & $\mathrm{kWh} / \mathrm{t}$ cane \\
\hline Biodiesel plant ${ }^{\mathrm{h}}$ & 22.3 & $\mathrm{kWh} / \mathrm{t}$ cane \\
\hline Surplus electricity & 79.6 & $\mathrm{kWh} / \mathrm{t}$ cane \\
\hline \multicolumn{3}{|l|}{ Production } \\
\hline Ethanol & 340,000 & $\mathrm{~m}^{3} / \mathrm{yr}$ \\
\hline Electricity & 527,500 & $\mathrm{MWh} / \mathrm{yr}$ \\
\hline Biodiesel & 34,850 & $\mathrm{t} / \mathrm{yr}$ \\
\hline Consumed & 13,380 & $\mathrm{t} / \mathrm{yr}$ \\
\hline Surplus & 21,470 & $\mathrm{t} / \mathrm{yr}$ \\
\hline
\end{tabular}

Carbon, nitrogen and phosphorus consumption for algae production are calculated assuming an algal composition of $\left[\mathrm{C}_{106} \mathrm{H}_{181} \mathrm{O}_{45} \mathrm{~N}_{15} \mathrm{P}\right]$ based on the Redfield Ratio (Table 3). We considered ammonia, single superphosphate and potassium chloride as sources of nitrogen, phosphorous and potassium, respectively [47]. The lipid content was assumed as $50 \%$ by weight, which is conservative [48]. Under laboratory conditions, Nannochloropsis salina can achieve $60 \%$ of lipid content by weight [48]. For the uncertainty analysis, the minimum (33\%) and maximum (61\%) values were defined according to Fábregas et al. [49]. Carbon dioxide from fermentation was determined by the stoichiometric conversion of glucose into ethanol and $\mathrm{CO}_{2}\left(90 \mathrm{~g} / \mathrm{mol}=46 \mathrm{~g} / \mathrm{mol}\right.$ ethanol $\left.+44 \mathrm{~g} / \mathrm{mol} \mathrm{CO}_{2}\right)$, resulting in $0.76 \mathrm{~g}$ of $\mathrm{CO}_{2}$ per liter of ethanol. We assumed the $\mathrm{CO}_{2}$ recovery efficiency to be $90 \%$ [13] and the $\mathrm{CO}_{2}$ utilization efficiency of algae to be $58 \%$ [50]. 
Table 3. Parameters of production and processing of algae and biodiesel

\begin{tabular}{|c|c|}
\hline Biodiesel production (t/yr) & 34,850 \\
\hline Chemicals input & kg/t algae (DW) \\
\hline Nitrogen $^{a}$ & 92.3 \\
\hline Phosphorus ${ }^{a}$ & 12.8 \\
\hline Potassium $^{\text {a }}$ & 8.2 \\
\hline Salt ${ }^{b}$ & 80 \\
\hline Glycerol $^{\mathrm{c}}$ & 126.6 \\
\hline Transesterification & kg/t biodiesel \\
\hline \multicolumn{2}{|l|}{ Chemicals input $^{\mathrm{d}}$} \\
\hline Ethanol & 154 \\
\hline Sodium methoxide & 33.4 \\
\hline Citric acid & 0,65 \\
\hline Hydrochloric acid & 9.5 \\
\hline Sodium hydroxide & 1.5 \\
\hline Sulphuric acid & 0.2 \\
\hline
\end{tabular}

Algae production is limited by the amount of $\mathrm{CO}_{2}$ available from cane juice fermentation. Thus, the algae production is function of $\mathrm{CO}_{2}$ utilization efficiency, algae carbon content, ethanol yield, and substrate consumption (glycerol). We assumed a fixed value for glycerol consumption, according to Sforza et al. [53], of $152 \mathrm{~g}$ per $\mathrm{kg}$ of biomass (DW). The additional carbon required to satisfy the mass balance of the algae carbon content comes from $\mathrm{CO}_{2}$, which justifies this input as a limiting factor for the algae supply.

Given that glycerol has a carbon content of $39 \%$, the organic carbon consumption is $59.6 \mathrm{~g} / \mathrm{kg}$ biomass. Thus, assuming a carbon content of $52.4 \%(\mathrm{w} / \mathrm{w})$ for $N$. salina [54], the total carbon required from flue gas $\left(\mathrm{CO}_{2}\right)$ is $464.3 \mathrm{~g} / \mathrm{kg}$ biomass, which corresponds to $1.7 \mathrm{t}$ $\mathrm{CO}_{2}$ per ton of algae (DW). However, an excess $\mathrm{CO}_{2}$ is necessary and, according to Rubio et al. [50], up to $40 \%$ of the $\mathrm{CO}_{2}$ may be lost during photoautotrophic growth, which corresponds to a real $\mathrm{CO}_{2}$ consumption of $2.9 \mathrm{t} \mathrm{CO}_{2}$ per ton of algae (Table 4). We did not include $\mathrm{CO}_{2}$ recirculation, which means that the unused carbon dioxide is released to atmosphere. 
Table 4. Carbon consumption in the mixotrophic reactor and photobioreactor

\section{Mixotrophic reactor}

Glycerol concentration in basic medium (\%; w/v)

Algae glycerol consumption efficiency (\%) ${ }^{\mathrm{a}}$

Glycerol consumption (g glycerol/L solution)

0.32

Biomass concentration $(\mathrm{g} / \mathrm{L})^{\mathrm{a}}$

2.1

Final consumption of glycerol (g glycerol/g biomass)

0.152

Glycerol C content (\%)

\section{Photobioreactor}

Carbon provided by $\mathrm{CO}_{2}$ from fermentation ( $\mathrm{g} \mathrm{C} / \mathrm{kg}$ biomass) ${ }^{\mathrm{d}}$

464.3

$\mathrm{CO}_{2}$ recovery from fermentation $\left(\mathrm{t} \mathrm{CO}_{2} / \mathrm{yr}\right)^{\mathrm{e}}$

219,900

$\mathrm{CO}_{2}$ utilization efficiency by algae $(\%)^{\mathrm{f}}$

58.3

Final $\mathrm{CO}_{2}$ consumption at PBR $\left(\mathrm{kg} \mathrm{CO}_{2} / \mathrm{kg}\right.$ biomass (DW))

2.92

\begin{tabular}{ll}
\hline Annual algae production (DW) (t/yr) & $\mathbf{7 5 , 2 7 0}$ \\
\hline
\end{tabular}

${ }^{\mathrm{a}}$ [53]. ${ }^{\mathrm{b}} 0.22 \mathrm{~kg} \mathrm{CO} / \mathrm{kg}$ biomass. ${ }^{\mathrm{c}}$ [54]. ${ }^{\mathrm{d}} 1.7 \mathrm{kgCO}_{2} / \mathrm{kg}$ biomass. ${ }^{\mathrm{e}} \mathrm{CO}_{2}$ recovery efficiency $=90 \%$ [13]. ${ }^{\mathrm{f}}[50]$.

Glycerol produced in the biodiesel plant $(4,800$ t/year) is insufficient to meet the algae's demand for organic carbon (14,300 t/year). Hence, the biorefinery needs an additional 9,500 ton per year of glycerin, which is equivalent to $2.9 \%$ of Brazilian glycerin production in 2012 [55]. We assumed that this additional glycerin is purchased from a soybean biodiesel plant whose environmental burdens was adapted from Souza and Seabra [56].

The lipid extraction is performed by using di-methyl ether (DME). The choice for this solvent is because DME consumes less energy and lower GHG emissions are associated with its life cycle, when compared with the hexane extraction [57].

Emission factors and fossil energy use for glycerin production were adapted from Souza \& Seabra [41] where the heat source for soybean oil extraction is a weighted mean of fuel oil, firewood and natural gas, in accordance with the energy consumption per source in the foods and beverages sector in Brazil [58].

The mass flows throughout the integrated system are presented in a Sankey diagram in the Supplementary Data (Figure S1).

\subsection{Uncertainty analysis}

The uncertainties were assessed through a detailed Monte-Carlo analysis. We used field and literature data to estimate the statistical parameters for the sensitivity and uncertainty 
analyses (Appendix E). Crystal Ball ${ }^{\circledR}$ was the tool employed to fit the probability distribution and to run the Monte-Carlo simulation.

\section{Results}

\subsection{Algae biodiesel life cycle assessment}

The Monte-Carlo analysis indicates that the life cycle GHG emissions of algae biodiesel are $23 \pm 3.5 \mathrm{gCO}_{2} \mathrm{e} / \mathrm{MJ}$ fuel (mean \pm std. dev.) (Figure 2). We calculated that algae biodiesel production uses $280 \pm 37 \mathrm{~kJ}$ of fossil/MJ fuel on a life cycle basis (Figure 3).

Batan et al. [48] and Delrue et al. [57] reported values around 40 and $80 \mathrm{gCO}_{2} \mathrm{e} / \mathrm{MJ}$ biodiesel for GHG emissions and 417 and $1075 \mathrm{~kJ} / \mathrm{MJ}$ for fossil energy use, respectively. Most of these emissions and fossil energy use are related to the energy and steam consumption for cultivation and processing of algae. In our LCA study, the energy demand is supplied by the cogeneration system of the ethanol plant.

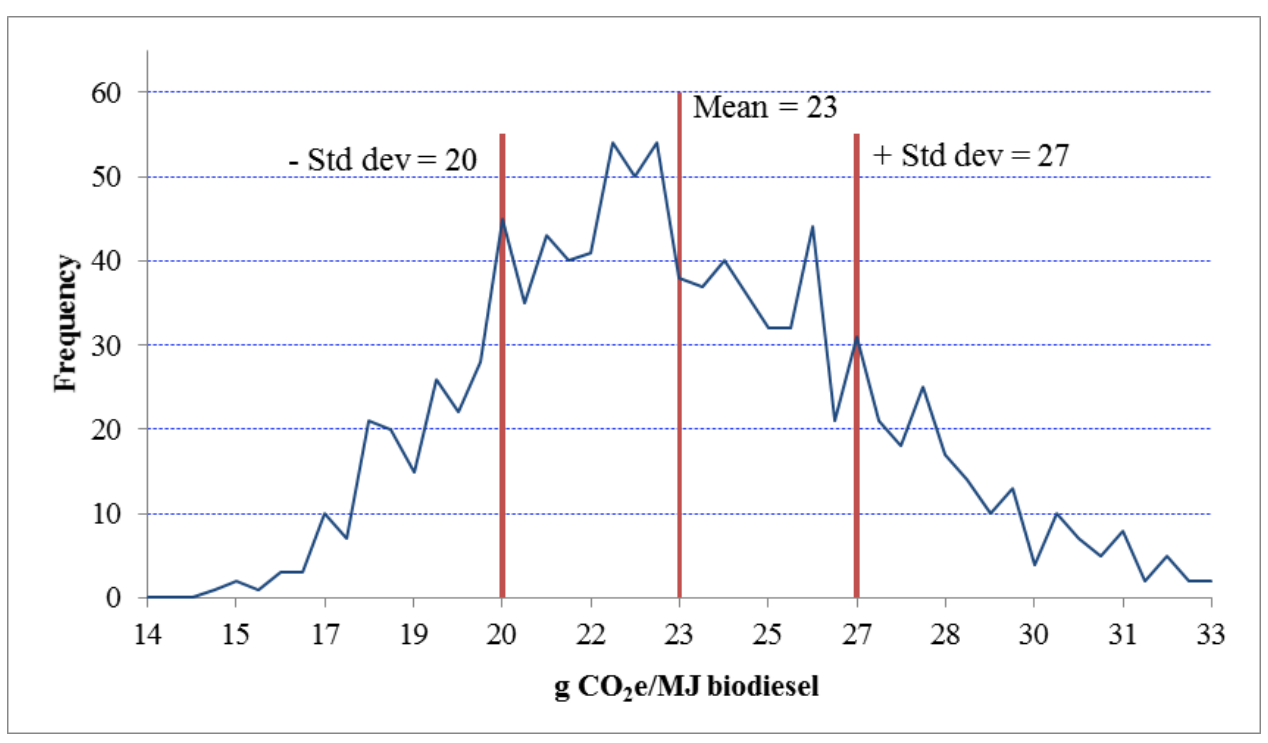

Figure 2. Algae biodiesel life cycle GHG emissions 


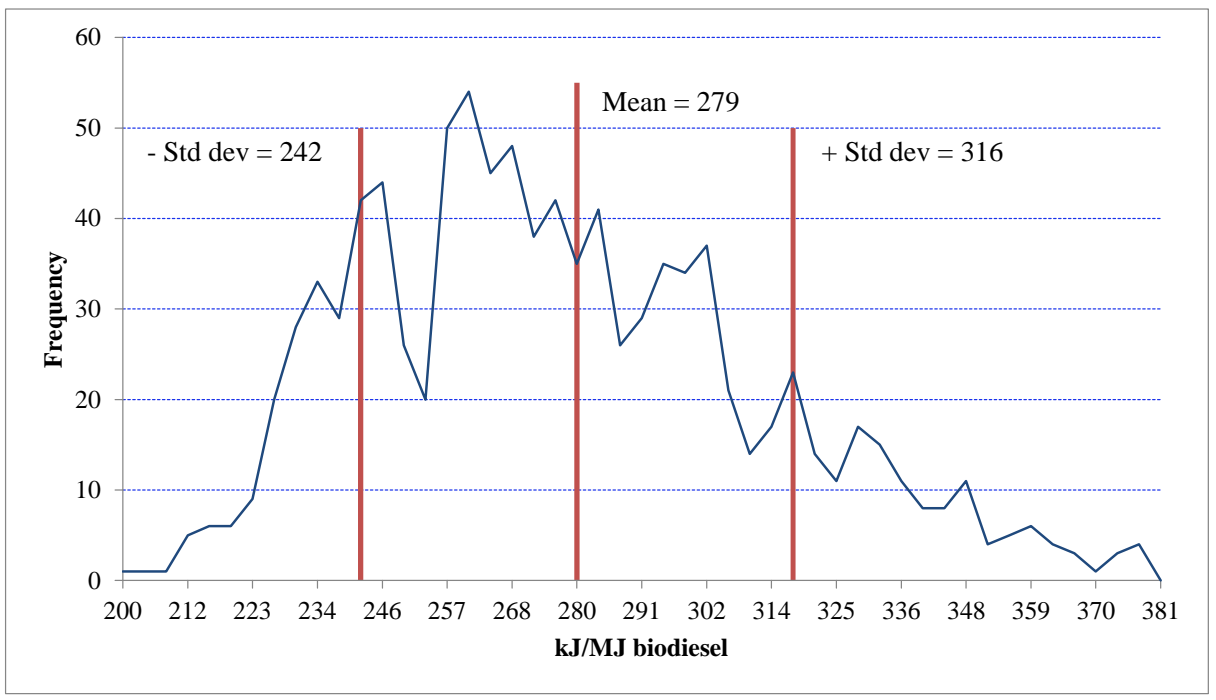

Figure 3. Algae biodiesel life cycle fossil energy use

$\mathrm{N}$ application rate, direct $\mathrm{N}_{2} \mathrm{O}$ emission from managed soil and glycerol consumption are responsible for about $27 \%, 26 \%$ and $19 \%$ of the variance in the GHG emissions, respectively. Glycerol content of glycerin accounts for $16 \%$ of the variance. As for fossil energy use, $\mathrm{N}$ application rate contributes to $79 \%$ of the variance in the results, followed by glycerol consumption (7.7\%) and $\mathrm{P}$ application rate $(5.7 \%)$ (Figure 4). 
Figure 4. Sensitivity analysis for the algae biodiesel life cycle: GHG emissions (a), fossil energy use (b).

Note: Only parameters with explained variation higher than $0.1 \%$ are presented. The units for the "*” parameters are presented in Table S4.

These life cycle indicators are considerably sensitive to the allocation method. Using price-based allocation instead of the mass-based procedure leads to greater life cycle impacts: $32 \pm 4.8 \mathrm{gCO}_{2} \mathrm{e} / \mathrm{MJ}$ (mean \pm std. dev.) for $\mathrm{GHG}$ emissions, and $380 \pm 54 \mathrm{~kJ} / \mathrm{MJ}$ for fossil energy use. The reason for that is because the price of biodiesel is nearly two times higher than the price of algae meal. The dispersion of the results and the standard deviations are also higher due to the high uncertainties regarding the products prices. This corroborated our option for the mass-based allocation for the base case assessment of the algae-sugarcane biorefinery. 


\subsection{Sugarcane ethanol life cycle assessment}

The integrated algae-sugarcane biorefinery can reduce the life cycle GHG emissions of ethanol from $23.5 \mathrm{gCO}_{2} \mathrm{e} / \mathrm{MJ}$ in the traditional system to $21 \mathrm{gCO}_{2} \mathrm{e} / \mathrm{MJ}$ (Figure 5). The sensitivity analysis shows that direct $\mathrm{N}_{2} \mathrm{O}$ emissions accounts for $58 \%$ of the variance, followed by sugarcane yield, which is responsible for $24 \%$. The significance of the direct $\mathrm{N}_{2} \mathrm{O}$ emissions is due to its wide variation in the probability distribution (Table S4).

In the reference case, residue use, including trash decomposition, stillage, filtercake, boiler ash, soot, and bagasse burning, account for 33\% of the GHG emissions over the traditional ethanol life cycle. Nitrogen use, which includes its production and direct and indirect emissions during the use, is responsible for $27 \%$ of the total emissions in the traditional case. Although the diesel represents $23 \%$ of the GHG emissions, it is responsible for around $2 \%$ of the variance in the $\mathrm{MC}$ analysis, even assuming $100 \mathrm{~L} / \mathrm{ha}$.yr of amplitude between minimum and maximum values. The major contributions to the dispersion of results come from the direct $\mathrm{N}_{2} \mathrm{O}$ emission (52\%) and sugarcane yield (30\%).

In the integrated biorefinery, where no diesel is consumed in the agriculture activities, algae biodiesel is responsible for only $6 \%$ of the life-cycle GHG emissions. Residues, nitrogen, and lime are responsible for $41 \%, 33 \%$ and 15\%, respectively (reference case). From the sensitivity analysis, we found that the direct $\mathrm{N}_{2} \mathrm{O}$ emissions from managed soil and sugarcane yield are the most influential parameters, responsible for $58 \%$ and $24 \%$ of the GHG emissions over the ethanol life cycle (Figure 6).

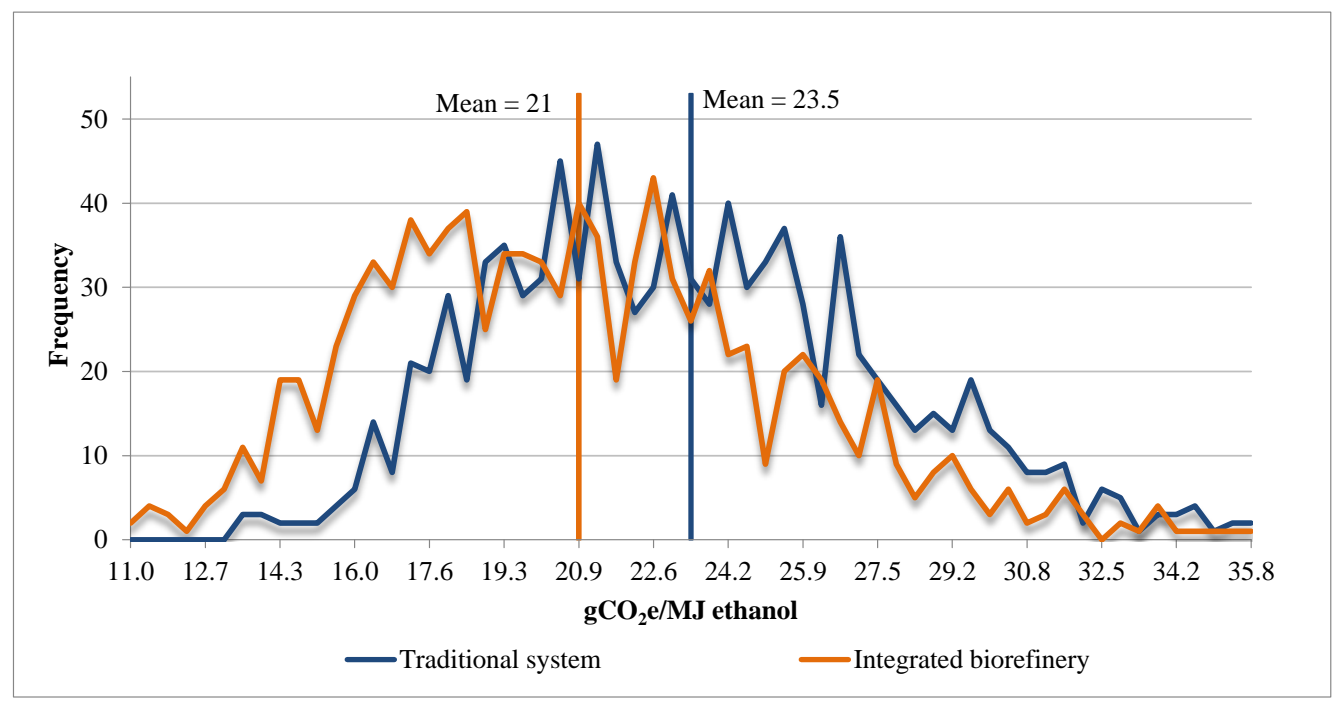

Figure 5. Monte-Carlo results for the GHG emissions - comparison between the traditional system and the integrated algae-sugarcane biorefinery. 
$\mathrm{gCO}_{2} \mathrm{e} / \mathrm{MJ}$ ethanol

\begin{tabular}{|c|c|c|c|c|}
\hline 5 & 15 & 20 & 25 & 30 \\
\hline Direct N2O emissions from managed soil $(\%)^{\star}$ & $0.44 \%$ & & & $2.77 \%$ \\
\hline Sugarcane yield (t/ha.yr) & 117.6 & & 52.4 & \\
\hline Indirect $\mathrm{N} 2 \mathrm{O}$ emissions - EF leaching * & 0.0018 & 0.0229 & & \\
\hline Ethanol yield (L/t sugarcane) & 95 & & & \\
\hline Indirect N2O emissions - Leaching fraction* & 0.14 & 0.74 & & \\
\hline Ratoon-cane $\mathrm{N}$ application rate (kg/ha.yr) & 66 & & & \\
\hline Indirect N2O emissions - EF volatilization * & 0 & & & \\
\hline Indirect N2O emissions - Volatilization fraction* & 0.04 & & & \\
\hline CO2 lost (fermentation) (\%) & $73 \%$ & & & \\
\hline $\mathrm{N}$ application rate - algae (g/kg biomass) & & & & \\
\hline
\end{tabular}

\begin{tabular}{|c|c|c|c|c|}
\hline & & J/MJ de ethanol & & \\
\hline & 40 & 60 & 80 & 100 \\
\hline Sugarcane Yield (t/ha.y) & 117.6 & & 52.4 & \\
\hline Ethanol yield (L/t cane) & & 95 & & \\
\hline Ratoon-cane $\mathrm{N}$ application rate (kg/ha.yr) & & $66 \square 93$ & & \\
\hline $\mathrm{N}$ application rate - algae (g/kg biomass) & & 93 & & \\
\hline Cane transportation distance $(\mathrm{km})$ & & $26-103$ & & \\
\hline Sugarcane diesel consumption (L/ha.y) & & $237 \square 324$ & & \\
\hline Glycerol consumption (g/g algal biomass) & & 0.117|| 0.187 & & \\
\hline P application rate - algae (g/kg biomass) & & 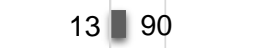 & & \\
\hline
\end{tabular}

Figure 6. Sensitivity analysis of the integrated algae-sugarcane biorefinery: ethanol's life cycle (a) GHG emissions, and (b) fossil energy use.

On energy use, the MC analysis shows that the integrated biorefinery is able to reduce fossil fuel consumption by approximately $50 \%$ compared to the traditional system. As noted in Figure 7, the traditional system has larger variance, 2.5 times higher than the integrated biorefinery. The reason for this is the diesel consumption, which represents about $25 \%$ of the dispersion of results in the traditional system.

In the reference case, nitrogen use is the second largest fossil energy use input, accounting for $25 \%$ in the traditional system. Diesel accounts for $63 \%$ of the fossil energy use. From the sensitivity analysis, diesel is responsible for about $10 \%$ of the variance in the MC analysis; sugarcane yield represents $66 \%$ of the variance, and sugarcane transportation distance accounts for $11 \%$, which is also directly related to the diesel consumption. 
In the integrated case, nitrogen and algae biodiesel are responsible for $53 \%$ and $21 \%$ of the fossil energy use, respectively (reference case). Once again, from the sensitivity analysis, we

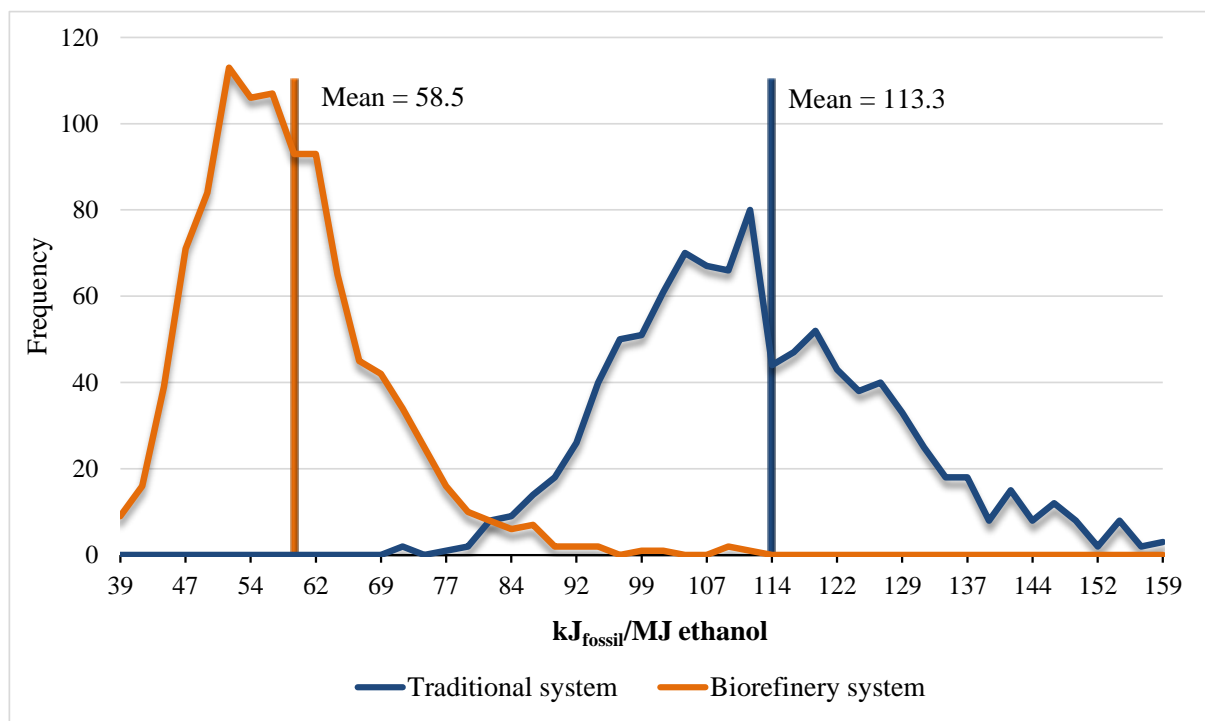

Figure 7. Monte-Carlo results for the fossil energy use - comparison between the traditional system and the integrated algae-sugarcane biorefinery.

\section{Discussion}

The MC simulation showed that the integration is more advantageous with respect to the reduction of fossil energy use. The uncertainty analysis also demonstrated that replacing diesel by biodiesel reduce the dispersion of the results for fossil energy use. However, a high variation is associated to the GHG emissions mainly because of the uncertainties related to the direct and indirect $\mathrm{N} 2 \mathrm{O}$ emissions from synthetic and organic fertilizers. For this reason, strategies to improve the management of synthetic fertilizers and residues are important additional actions to reduce the GHG emissions in the sugarcane ethanol life cycle.

The glycerol consumption in our model corresponds to $2.9 \%$ of the total national production (up to 300,000 tons per year). Although glycerol is widely available due to the large biodiesel production in Brazil and has a low market price, this carbon source can be constrained depending on the biodiesel plant location.

Regarding the $\mathrm{CO}_{2}$ use, it is important to highlight that if fermentation is the only source, algae production will follow the ethanol production season, which is interrupted for at least 3 months each season. For this reason, an economic assessment should be performed to 
identify which $\mathrm{CO}_{2}$ source would be more feasible: $\mathrm{CO}_{2}$ from fermentation or $\mathrm{CO}_{2}$ from biomass burning. Ideally, a plant should work 12 months per year to keep the algae alive. In exclusive boiler running with biomass (stored bagasse). Note that many sugarcane mills are already producing electricity during the sugarcane offseason. Again, an economic assessment will indicate which option is more economically attractive. In our model, we did not consider the $\mathrm{CO}_{2}$ from biomass burning because the carbon dioxide supplied by fermentation is sufficient to replace $100 \%$ of the onsite diesel demand.

In order to assess the likelihood that the proposed integrated biorefinery will be built, we looked at Brazilian biodiesel policy and market conditions. Brazilian federal law $\mathrm{n}$. 11097/2005 requires a blend of 5\% biodiesel and 95\% diesel by volume (B5), except for maritime diesel. The biodiesel commercialization is carried out through public auctions organized by Petrobrás and the Brazilian National Agency of Petroleum, Natural Gas and Biofuels (ANP). The average price of biodiesel in the auction has decreased in recent auctions, but it is still higher than the diesel price. For this reason, the Brazilian policy has supported the biodiesel production and commercialization. Therefore, it is important to note that although replacing diesel by biodiesel in a sugarcane ethanol biorefinery may result in lower life cycle GHG emissions and fossil energy use, biorefinery owners are more likely to sell algae biodiesel on the market and continue to use petroleum diesel for operations. Hence, in the absence of any environmental performance incentives, the integrated system we propose may operate differently in practice. Further, Omega-3 production can also be more attractive than biodiesel production given its high market price. However, this market can be limited by the total demand and by the location.

As for the assumptions made in the algae production system, there are still many uncertainties regarding the algae yield under different locations and process conditions as well as technological barriers, especially for production and de-watering. All these conditions could affect the results of this study. Although this study has given special attention to the uncertainties of the parameters, it is important to develop further studies including different technological and process conditions as well as an economic assessment.

Estimates of production costs have showed values between US $\$ 2.38$ and US $\$ 7.93$ per liter when algae is produced in open ponds, and between US\$3.96 and US\$10.57 per liter when photobioreactor is used [8]. Thus, the microalgae biodiesel is not cost-effective yet to compete with diesel unless additional support such as subsidies are applied [6]. 


\section{Conclusion}

The significant contribution from diesel consumption to the environmental profile of sugarcane ethanol encourages the pursuit for production systems less reliant on fossil fuels. Previous analyses have shown that the displacement of diesel by biodiesel can help not only in the mitigation of some environmental burdens of sugarcane ethanol, but also curb logistical issues in Brazil. In this work, we evaluated a proposed algae-sugarcane biorefinery that combines the production of ethanol and algae biodiesel, which can be used as diesel substitute in the sugarcane cultivation activities. The results show that such system is be able to reduce the GHG emissions and, especially, the fossil energy use in the ethanol life cycle.

Uncertainties, however, are high as the analysis relied on projected performances, while there are still significant technological and economical barriers associated with algae biodiesel. On the other hand, the integration can be alternatively viewed as a promising pathway for the deployment of algae biodiesel in face of the local availability of pure $\mathrm{CO}_{2}$ streams and utilities. Despite representing a good option to improve the environmental performance of ethanol, those gains may not be observed in the absence of economic incentives, as operators may choose to not displace diesel, or to produce other algae-based products with higher added-value.

\section{ACKNOWLEDGMENT}

Authors thankfully acknowledge the financial support from FAPESP and the technical support from SEE ALGAE Technology Company who provided access to their confidential data. Part of this work was supported by the Director, Office of Science, of the US Department of Energy under Contract No. DE-AC02-05CH11231. 


\section{REFERENCES}

[1] Lundquist TJ, Woertz IC, Quinn NWT, Benemann JR. A realistic technology and engineering assessment of algae biofuel production 2010.

[2] Wijffels RH, Barbosa MJ. An Outlook on Microalgal Biofuels. Science 2010;329:7969. doi:10.1126/science.1189003.

[3] Petkov G, Ivanova A, Iliev I, Vaseva I. A critical look at the microalgae biodiesel. Eur J Lipid Sci Technol 2012;114:103-11. doi:10.1002/ejlt.201100234.

[4] $\mathrm{Xu} \mathrm{H}$, Miao X, Wu Q. High quality biodiesel production from a microalga Chlorella protothecoides by heterotrophic growth in fermenters. J Biotechnol 2006;126:499-507. doi:10.1016/j.jbiotec.2006.05.002.

[5] Satyanarayana KG, Mariano AB, Vargas JVC. A review on microalgae, a versatile source for sustainable energy and materials. Int J Energy Res 2011;35:291-311. doi:10.1002/er.1695.

[6] Mata TM, Martins AA, Caetano NS. Microalgae for biodiesel production and other applications: A review. Renew Sustain Energy Rev 2010;14:217-32. doi:10.1016/j.rser.2009.07.020.

[7] Ahmad AL, Yasin NHM, Derek CJC, Lim JK. Microalgae as a sustainable energy source for biodiesel production: A review. Renew Sustain Energy Rev 2011;15:584-93. doi:10.1016/j.rser.2010.09.018.

[8] Sikes K, van Walwijk M, McGill R. Annex XXXIV Biomass Derived Diesel Fuels. Canada, Finland, Japan (LEVO), Thailand, USA: IEA Advanced Motor Fuels, IEA Energy Technology Network; 2011.

[9] Franz A, Lehr F, Posten C, Schaub G. Modeling microalgae cultivation productivities in different geographic locations - estimation method for idealized photobioreactors. Biotechnol J 2012;7:546-57. doi:10.1002/biot.201000379.

[10] Seabra JEA, Macedo IC, Chum HL, Faroni CE, Sarto CA. Life cycle assessment of Brazilian sugarcane products: GHG emissions and energy use. Biofuels Bioprod Biorefining 2011;5:519-32. doi:10.1002/bbb.289.

[11] CONAB. Brazilian crop assessment: sugarcane, crop 2013/2014, Second Estimate. Brasília: National Food Supply Company; 2013.

[12] EPE. Brazilian Energy Balance 2013, Year 2012. Rio de Janeiro: Brazilian Energy Research Office; 2013.

[13] Filho RB de A, Danielski L, de Carvalho FR, Stragevitch L. Recovery of carbon dioxide from sugarcane fermentation broth in the ethanol industry. Food Bioprod Process 2013;91:287-91. doi:10.1016/j.fbp.2012.09.009.

[14] Brennan L, Owende P. Biofuels from microalgae-A review of technologies for production, processing, and extractions of biofuels and co-products. Renew Sustain Energy Rev 2010;14:557-77. doi:10.1016/j.rser.2009.10.009.

[15] Carlsson AS, van Beilen JB, Möller R, Clayton D. Micro- and macro-algae: utility for industrial applications. University of York, UK: CPL Press; 2007.

[16] Chojnacka K, Marquez-Rocha F-J. Kinetic and Stoichiometric Relationships of the Energy and Carbon Metabolism in the Culture of Microalgae. Biotechnology 2004;3:21-34. doi:10.3923/biotech.2004.21.34.

[17] Mata TM, Martins AA, Caetano NS. Microalgae for biodiesel production and other applications: A review. Renew Sustain Energy Rev 2010;14:217-32. doi:10.1016/j.rser.2009.07.020.

[18] Chisti Y. Biodiesel from microalgae. Biotechnol Adv 2007;25:294-306. doi:10.1016/j.biotechadv.2007.02.001. 
[19] Williams PJ le B, Laurens LML. Microalgae as biodiesel \&amp; biomass feedstocks: Review \&amp; analysis of the biochemistry, energetics \&amp; economics. Energy Environ Sci 2010;3:554. doi:10.1039/b924978h.

[20] Darzins A, Pienkos P, Edye L. Current Status and Potential for Algal Biofuels Production. International Energy Agency (IEA) Bioenergy Task 39; 2012.

[21] Demirbas A, Demirbas MF. Importance of algae oil as a source of biodiesel. Energy Convers Manag 2011;52:163-70. doi:10.1016/j.enconman.2010.06.055.

[22] Lam MK, Lee KT. Microalgae biofuels: A critical review of issues, problems and the way forward. Biotechnol Adv 2012;30:673-90. doi:10.1016/j.biotechadv.2011.11.008.

[23] Sikes K, van Walwijk M, McGill R. Algae as a Feedstock for Biofuels: An Assessment of the State of Technology and Opportunities. vol. Annex XXXIV Subtask 2. IEA Advanced Motor Fuels; 2010.

[24] Davis R, Aden A, Pienkos PT. Techno-economic analysis of autotrophic microalgae for fuel production. Appl Energy 2011;88:3524-31. doi:10.1016/j.apenergy.2011.04.018.

[25] Uduman N, Qi Y, Danquah MK, Forde GM, Hoadley A. Dewatering of microalgal cultures: A major bottleneck to algae-based fuels. J Renew Sustain Energy 2010;2:012701. doi:10.1063/1.3294480.

[26] Darzins A, Pienkos P, Edye L. Current Status and Potential for Algal Biofuels Production. International Energy Agency (IEA) Bioenergy Task 39; 2012.

[27] Halim R, Danquah MK, Webley PA. Extraction of oil from microalgae for biodiesel production: A review. Biotechnol Adv 2012;30:709-32. doi:10.1016/j.biotechadv.2012.01.001.

[28] Hoekman SK. Biofuels in the U.S. - Challenges and Opportunities. Renew Energy 2009;34:14-22. doi:10.1016/j.renene.2008.04.030.

[29] SAT. Company data - See Algae Technology 2013.

[30] Sforza E. Oil from microalgae:: species selection, photobioreactor design and process optimization. PhD. Universtità Degli Studi di Padova, 2012.

[31] Jiang Y, Zhang W, Wang J, Chen Y, Shen S, Liu T. Utilization of simulated flue gas for cultivation of Scenedesmus dimorphus. Bioresour Technol 2013;128:359-64. doi:10.1016/j.biortech.2012.10.119.

[32] Ryu HJ, Oh KK, Kim YS. Optimization of the influential factors for the improvement of CO2 utilization efficiency and CO2 mass transfer rate. J Ind Eng Chem 2009;15:4715. doi:10.1016/j.jiec.2008.12.012.

[33] Fazal MA, Haseeb ASMA, Masjuki HH. Biodiesel feasibility study: An evaluation of material compatibility; performance; emission and engine durability. Renew Sustain Energy Rev 2011;15:1314-24. doi:10.1016/j.rser.2010.10.004.

[34] Kalam M., Masjuki H. Biodiesel from palmoil-an analysis of its properties and potential. Biomass Bioenergy 2002;23:471-9. doi:10.1016/S0961-9534(02)00085-5.

[35] ISO 14040. Environmental Management - Life Cycle Assessment: Principles and Framework. 2006.

[36] ISO 14044. Environmental Management - Life Cycle Assessment: Requirements and Guidelines. 2006.

[37] Ecoinvent Centre. Database. Swiss Centre for Life Cycle Inventories; 2012.

[38] Chagas MF, Cavalett O, Silva CRU, Seabra JEA, Bonomi A. Adaptação de inventários de ciclo de vida da cadeia produtiva do etanol. III Congr. Bras. Em Gest. Ciclo Vida Prod. E Serviços, vol. 1, Maringá, Paraná, Brasil: DentalPress Publishing; 2012, p. 1-6.

[39] Cavalett O, Junqueira TL, Dias MOS, Jesus CDF, Mantelatto PE, Cunha MP, et al. Environmental and economic assessment of sugarcane first generation biorefineries in Brazil. Clean Technol Environ Policy 2012;14:399-410. doi:10.1007/s10098-011-04247. 
[40] Bonomi A, Mariano AP, Jesus CDF, Franco HCJ, Cunha MP, Dias MOS, et al. The Virtual Sugarcane Biorefinery (VSB): 2011 Report. Campinas, São Paulo: Brazilian Bioethanol Science and Technology Laboratory (CTBE); 2012.

[41] Souza SP, Seabra JEA. Assessment of Environmental and Economic Aspects of the Integrated Production of Ethanol and Biodiesel. 21st Eur. Biomass Conf. Exhib., Copenhagen: 2013.

[42] Hassuani SJ, Leal MRLV, Macedo IC. Biomass power generation: sugar cane bagasse and trash. Piracicaba, SP, Brazil: Programa das Nações Unidas para o Desenvolvimento (PNUD) and Centro de Tecnologia Canavieira (CTC); 2005.

[43] IPCC, Prepared by the National Greenhouse Gas Inventories Programme, Eggleston H.S., Buendia L., Miwa K., Ngara T. and Tanabe K. (eds). 2006 IPCC Guidelines for National Greenhouse Gas Inventories. Japan: IGES; 2006.

[44] Dias MOS, Cunha MP, Jesus CDF, Rocha GJM, Pradella JGC, Rossell CEV, et al. Second generation ethanol in Brazil: Can it compete with electricity production? Bioresour Technol 2011;102:8964-71. doi:10.1016/j.biortech.2011.06.098.

[45] SAT. Company data - See Algae Technology 2013.

[46] Delrue F, Setier P-A, Sahut C, Cournac L, Roubaud A, Peltier G, et al. An economic, sustainability, and energetic model of biodiesel production from microalgae. Bioresour Technol 2012;111:191-200. doi:10.1016/j.biortech.2012.02.020.

[47] Lardon L, Hélias A, Sialve B, Steyer J-P, Bernard O. Life-Cycle Assessment of Biodiesel Production from Microalgae. Environ Sci Technol 2009;43:6475-81. doi:10.1021/es900705j.

[48] Batan L, Quinn J, Willson B, Bradley T. Net Energy and Greenhouse Gas Emission Evaluation of Biodiesel Derived from Microalgae. Environ Sci Technol 2010;44:797580. doi:10.1021/es102052y.

[49] Fábregas J, Maseda A, Domínguez A, Otero A. The cell composition of Nannochloropsis sp. changes under different irradiances in semicontinuous culture. World J Microbiol Biotechnol 2004;20:31-5. doi:10.1023/B:WIBI.0000013288.67536.ed.

[50] Rubio FC, Fernandez FG, Perez JA, Camacho FG, Grima EM. Prediction of dissolved oxygen and carbon dioxide concentration profiles in tubular photobioreactors for microalgal culture. Biotechnol Bioeng 1999;62:71-86. doi:10.1002/(SICI)10970290(19990105)62:1<71::AID-BIT9>3.0.CO;2-T.

[51] Redfield AC. The biological control of chemical factors in the environment. Am Sci 1958;46:205-21.

[52] Oliverio JL, Barreira ST, Rangel SCP. Integrated biodiesel production in Barralcool sugar and alcohol mill. Int Sugar J 2007;109:12.

[53] Sforza E, Cipriani R, Morosinotto T, Bertucco A, Giacometti GM. Excess CO2 supply inhibits mixotrophic growth of Chlorella protothecoides and Nannochloropsis salina. Bioresour Technol 2012;104:523-9. doi:10.1016/j.biortech.2011.10.025.

[54] Sforza E, Bertucco A, Morosinotto T, Giacometti GM. Photobioreactors for microalgal growth and oil production with Nannochloropsis salina: From lab-scale experiments to large-scale design. Chem Eng Res Des 2012;90:1151-8. doi:10.1016/j.cherd.2011.12.002.

[55] ANP. Biocombustíveis, Biodiesel: Boletim mensal do biodiesel, Jan-Dez 2012. Agência Nacional de Petróleo, Gás Natural e Biocombustíveis.; 2013.

[56] Souza SP, Seabra JEA. Environmental benefits of the integrated production of ethanol and biodiesel. Appl Energy 2013;102:5-12. doi:10.1016/j.apenergy.2012.09.016. 
[57] Delrue F, Setier P-A, Sahut C, Cournac L, Roubaud A, Peltier G, et al. An economic, sustainability, and energetic model of biodiesel production from microalgae. Bioresour Technol 2012;111:191-200. doi:10.1016/j.biortech.2012.02.020.

[58] EPE. Brazilian Energy Balance 2012: Year 2011 - Rio de Janeiro 2012. https://ben.epe.gov.br/downloads/Relatorio_Final_BEN_2012.pdf (accessed June 3, 2013). 